\title{
睪丸胎生細胞癌の皮下転移症例
}

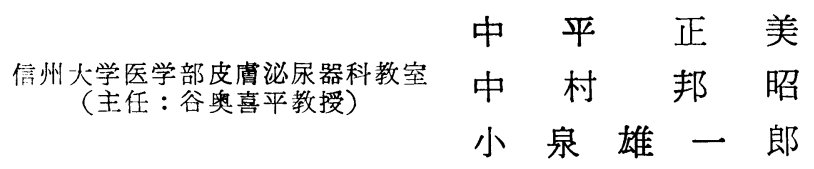

\section{A CASE OF SUBCUTANEOUS METASTASIS OF EMBRYONAL CELL CARCINOMA OF TESTICLE.}

\author{
Masami Nakahira, Kuniaki Nakamura, \\ Yuichiro Koizumi \\ Department of Dermatology and Urology, \\ School of Medicine, University of Shinshu
}

(Director: Prof. K. Tanioku)

皿丸炕発生する惡性腫瘍は男子の全惡性腫瘍の約 1\% を占めるに過ぎず頻度は大きいものと云えないが, 泌尿 器科患者枋てみると $3 \sim 5 \%$ を示すと思われ決し て軽視さるべき疾患ではない. 特に胎生細胞癌 (embryonal cell carcinoma) と呼ばれるものは, 発病初期に 既に身体各所に転移を来たし, 惡性度が高く予後不良と されるが, 我々の今回遭遇した鋅丸胎生細胞癌患者では, 特に皮下にも転移があり，乙のような症例は文献でも報 告が殆んごない点に興味があつたので報告し, 併せて新 抗腫瘍剤のへマトポルフイリン水銀を使用して経過を追 つたので，その成績などについても記載したい.

\section{症例}

中島某. 65才男性, 無職, 初診1960年 9 月12日.

主訴 : 左莘丸と左肩, 後頭, 側頭部皮下などの畽瘤形 成.

家族歴. 特記すべき事はない。癌の Belastung もな し. 子供は 8 人で皆健康.

既往歴: 50才の時, 糖尿病ではないかと医師から云わ れた事があるが, その後身体に特に異常ない。睪丸なぞ に外傷の既往症なく, 性病恰否定. 流行性耳下腺炎にも 罹患していない。

現病歴. 1959年 6 月に何等の誘因なく左側䔂丸が無痛 性に腫脹して来たのに気付い㣽. 以後, 何等の病的感覚 のないま く徐たに腫大. 1960年 4 月に, 頭部, 庄肩, 左鎖骨部，左前腕部などにやはり無痛性に腫济出現，漸 時増大する. 7 月に左上眼瞼部にも腫瘤出現, 赤味が強
く、“まばたき”にも邪魔で所謂，“目の上のたん瘤” の状態となり最初に本学眼科受診, 次いで当科に迴され て来た. この疾患を除けば健康で全身に病感なく, 膀胱 症状, 排尿異常もない.

現症 : 体格や>小さが栄養普通. 胸腹部所見は理学 的に大体正常だが, 肝は 1 横指ふれ, 両腎とも軽く触れ る. 胸部の一部に乾性ラ音を聞く. 女性化乳房なく前立 腺も正常である.

原発と思われる左宰丸腫瘍は, 超鷄卵大で表面は凹凸 不整, 硬度は全般に固いが, 場所により, ある程度硬度 に差がある。一部には波動を感ずる。陰囊とは部分的に 瘾着して扔り該当皮覤面は固い。副睪丸は判然としな い. 精管の基部に於ては, 大豆大のかなり固い腫瘤を 2 コ程触れる．転移したものとして体表から触れるものに 淋巴節転移, 皮下転移及び骨転移巣とがあり, 前者とし

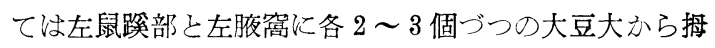
指頭大のものがあり, 左側䅡部にもそれと思われるもの があるが，左鎖骨上窝には触れない。後腹膜腔などは判 然としない。一方皮下に於ける転移としては，（第1 図，第 2 図）左上眼瞼，左鎖骨部皮下，左右肩胛骨及び 扇部皮下, 左前腕部皮下などにあり，また後頭，右側頭 などには骨と皮膚の間に亘る腫瘤があり, さらに左側頝 部の $3 \sim 4$ 個の腫㢞のうちの少なくとも 1 個は明膫に皮 膚自身汇も腫瘍性の変化を認める.以上のもの活いずれ も拇指頭大から胡桃大までで, 硬度ば弾性硬だが, 頭部 にあるものは, むしろ柔かい. 色調㴽常色近いもの办 
第 1 図左肩胛部転移巣

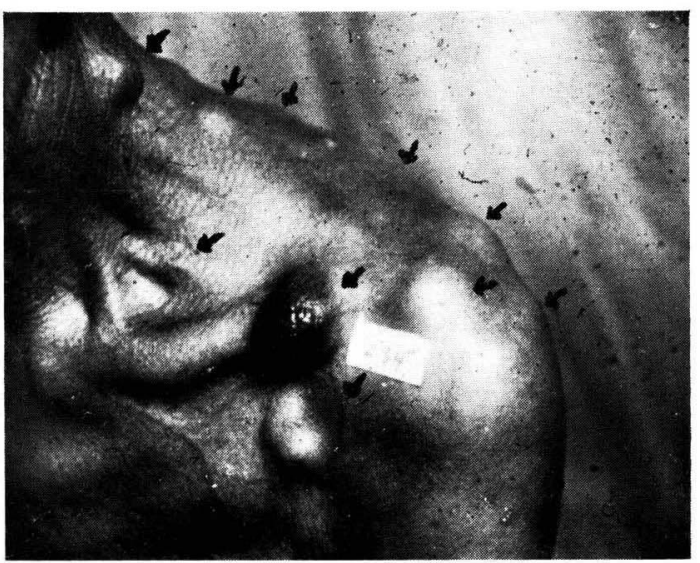

第 3 図 頭部 X 線写真（管転移柴）

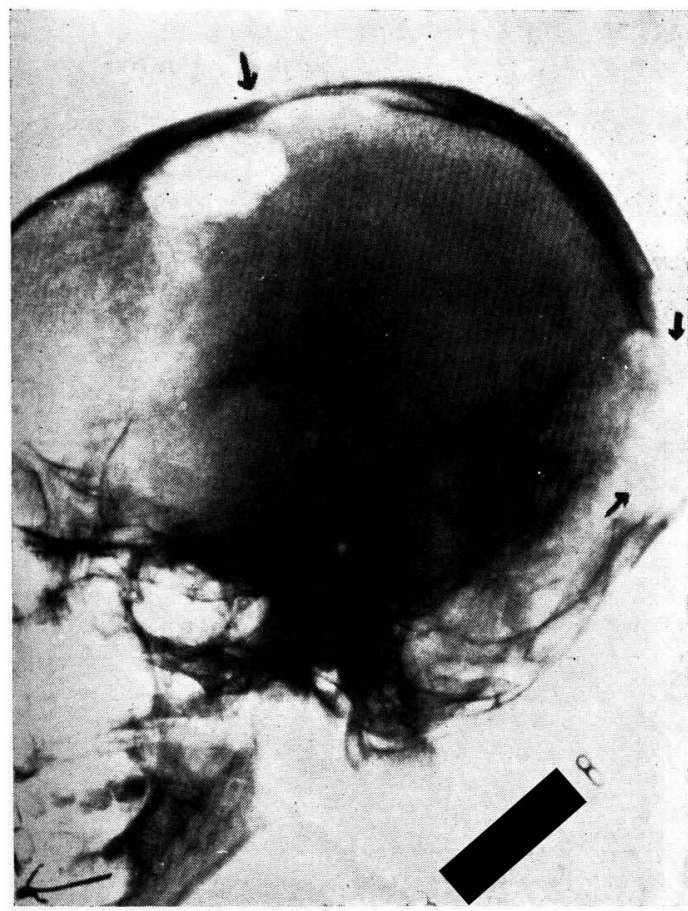

第 2 戍 左上眼瞼部転移巢

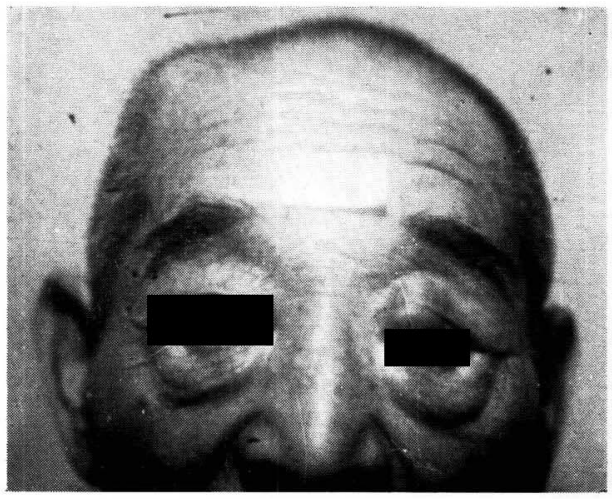

第 4 晓和35年12月14日米院時所見左前腕部腫瘤

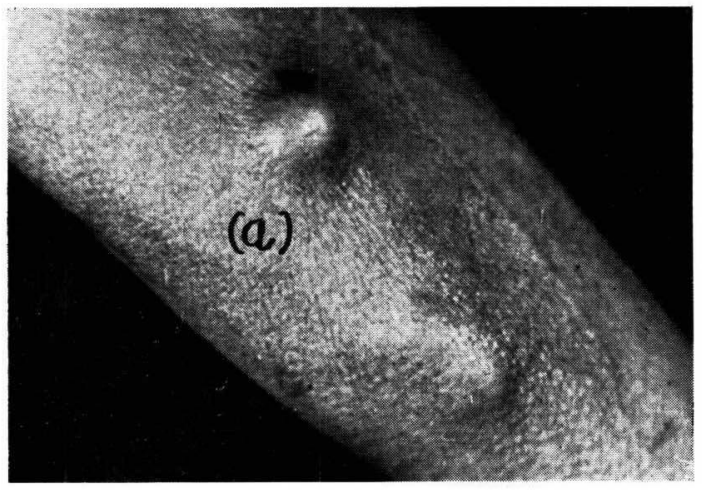

第 5 図 昭和36年 2 月 1 日米院將所見

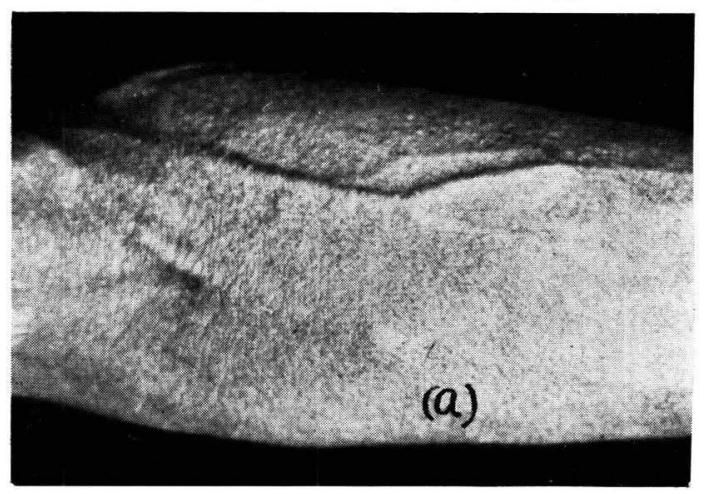




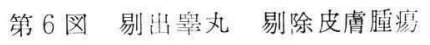

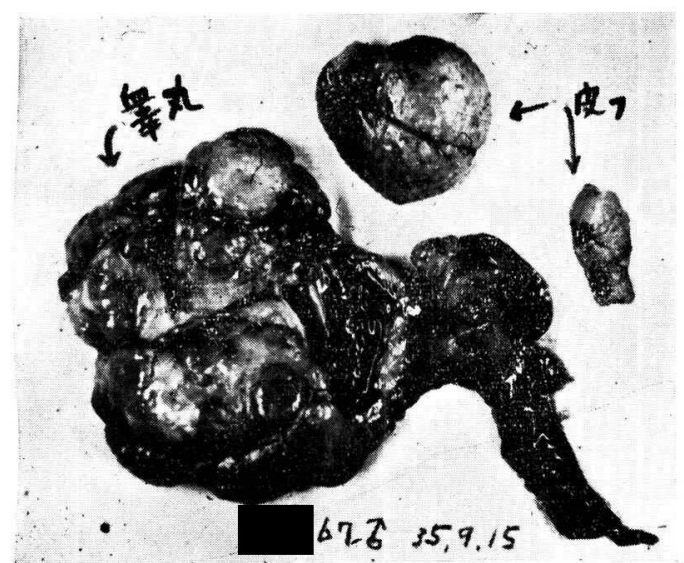

第 8 図皮下転移栄組織（抲执犬）

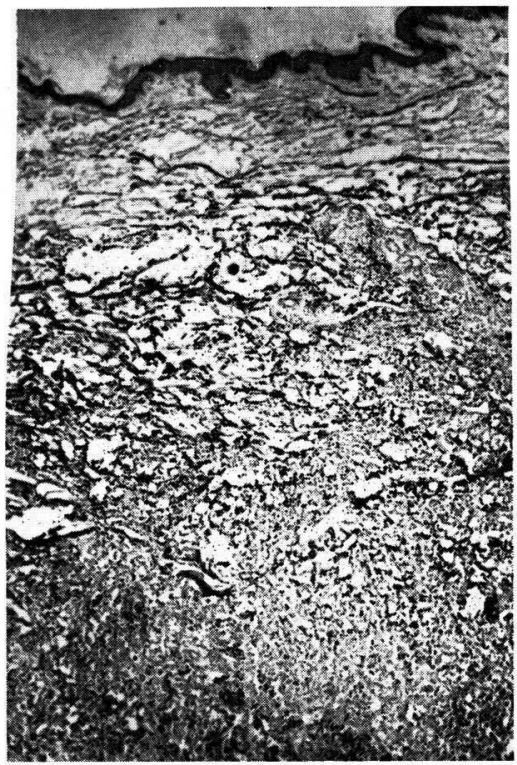

ら桃実色のものなどあるが，左鎖骨部皮膚のものや，左 上眼瞼部のものは表面に毛細血管の拡張が著明である. 皮膚と腫瘤は緊密に連絡している如くで皮膚自体にも变 化が及び, 腫瘤の基底部に対しても境界は判然としな w.

臨床諸検查成績 : レ線撮影を見ると頭部では腫瘤のあ る部に一致して（第 3 図）頭蓋骨にも欠損があり，骨転 移と見られる。李た胸部し線撮影像を見ると左上肺野に 円形ではないが, や>境界不鮮で超鳩卵大の転移巣と思 われる陰影がある.しかし上昇気球様ではない. 梞た胸
第 7 図 辠丸腫湯組織（強拡大）

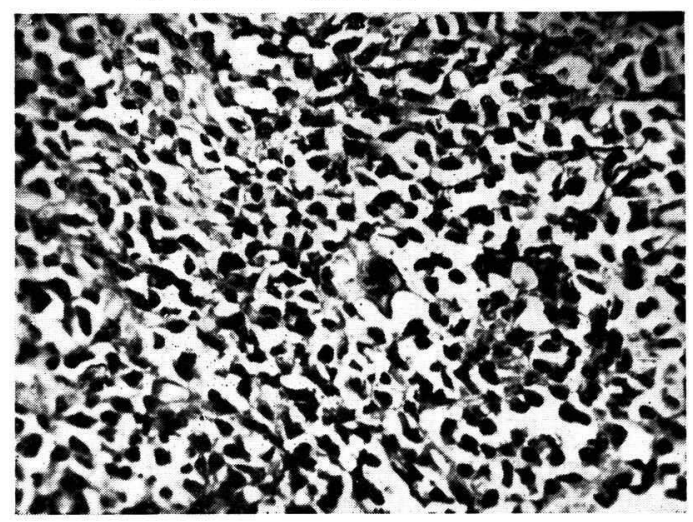

膜炎様の所見もなく縱隔洞もきれいである。血液所見で は赤血球数 390 万. 白血球数 7000 . 血沈素はザーリー法 で90\%. 血色素係数1.15. 血沈は 1 時間20, 2 時間 34 . 血清梅表汉応沈, カーン氏法, 緒方氏法, 硝子板法いず れも陰性である。

尿は蛋白, 糖ともに㓌性, ウロビリノーダン正常陽性 で沈稍は得られなかつた。

肝, 腎機能検查では PSP は初発 $5^{\prime} 15^{\prime \prime}, 2$ 時間合計 70\%. BSP 試験は 45 分で $0 \%$ あつた.

処置：左鋅丸は除辠術を行い，あわせて鼠蹊淋巴䬣廓 清老行つたが, 後腹膜腔淋巴節の廓清は行わなかつた. 左上眼瞼部のものは主として美容的, 精神的な面を考慮 して剔除した．左鎖骨部皮膚転移巣は組織学的検查の ため剔除した. 手術後, 第 1 製薬より試供品の提供を 受け, 新抗腫瘍荗へマトポルフィリン水銀 $(\mathrm{MH})$ を用 い, 1 筒 $25 \mathrm{mg}$ 静注, 40 日間に計20本 (隔日), 更にそれ以 後は約 1 週間間隔で 5 本使用した. この間頭部の腫瘤の あるものが硬度やや軟になつた変化は見られたが, 全般 的にみると腫瘍が積極的に縮小するには到らず, 概ね不 変であつた.この間腫瘤の新生は認められなかつたが, 上記治療終了後 1 週間して12月14日来院時には前腕, 背 部などに再び腫溜の新生をみた. 左前腕のものは第 4 涩 に示すどとく上方のものは胡桃大，下方のものは 2 個の 示指頭大のものであつた. そとで再び同日より隔日に MH $25 \mathrm{mg}$ 劣昭和 36 年 1 月 6 日まで計 10 本（はじめからは 計35本）を使用したが, 患者の都合により以後中止し た.しかるに 2 月 1 日来院せる際みると, 左前腕の最も 大きかつた胡桃大の腫痬は大豆大に縮小扁平化し, 他の 2 個は完全に消失していた（第 5 図）.この間の経過を患 者から聞くと，1月10日頃より腫㓪は目に見えて縮小し 
はじめ, 䄪 1 週間位の期間に左前腕，頝部，背部等の腫 箇が相前後して消失していつたという．現在は右前頭部 及び左肩胛部にある大きな畽瘤のみとなり，全身状態む 極めて良好である. 副作用は認めなかつた。

以上の治療経過よりしてへマトポルフィリン水銀は, 章丸胎生細胞癌の皮下転移に対し 30 本以下では 1 部のも のの軟化はあつたが全般的にみると積極的に腫演が縮小 あるいは消失するには 到らず，腫留の新生もみられた が，更に使用を継続することにより，腫瘤の縮小更に消 失するに到つたもので，すぐれた効果を示したものと考 える.

摘出腫瘤の肉眼的所見: (第 6 図) 左殬丸は大きさ $4.5 \times 4.5 \times 8 \mathrm{~cm}$, 重さ $105 \mathrm{~g}$. 表面は, かなり凹凸不整 割面は灰白黄色髄梯でその中に直径 $1 \mathrm{~cm}$ から $1.5 \mathrm{~cm}$ 位の 球形の殊に固く軟骨様硬を示し, や〉赤味のある腫瘤が 5 個程ある（第 6 図の大きな腫瘍塊の中に小円形として あるもの).皮下転移部のもの注割合比判然と周囲から区 画された略こ球形の固い腫瘤で割面は灰黄色で構造均一 で壊死などは見られない。

組織学的所見 : 暻丸の腫瘍について述べると, H.E. 染色で部分的に割合均質の細胞の配列する所がある. 境 界はやや不明膫だが多面体をなす細胞が湖漫性に存在し

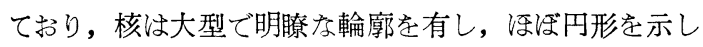
ている. 細胞間質は, 一部に円形細胞の浸潤があり, 全 体として壊死治んごなく出血が一部諗められる. 即 ち seminoma の像を示す所もある.しかし上記の如き 部分は一部であつて残りの大部分は seminoma と云い 難く, むしろ鋅丸胎生細胞癌と云われるものである. 即 ち組織学的に極めて变化に富九だ種々の形を示し, 全般 として,相当に未分化の細胞が多く,一部に分裂像もみら れ, 未分化各期の像がみられる. 核は種々の染色度走示 し, 型も円形, 卵形, その他不整形を示している. 間質 は全般に乏しく, 部分的には血管の増生をみる. 壊死出 血はない. 組織学的所見を緾めてみると, 先の肉眼的所 見で述べた割面に存在した数個の固い球形の腫瘤塊が胎 生細胞癌であり，その周辺にあつた組織が seminoma 様の構造を示していた。

また左上眼瞼部抬よび左鎖骨部皮下の転移部の組織像 も, 精管にそつた箤丸周囲の転移部からの組織像も鋅丸 において見られた胎生細胞癌と同様の所見を示した（第 7 図, 第 8 図).

$$
\text { 考按 }
$$

睪丸腫瘍は組織学的に非常に多様で, かつ, 総ての種
類の腫瘍の発生する可能性があり, この分類や発生病理 をめぐつての学説が甚だ多く，乙れらを整然と分類する 事は不可能に近い。この病理組織学的解明が他臓器に於 けるそれに比して明らかでないのは即ち, 他臓器に於け るより以上に発生原因も不明とされているためであろ 3 .

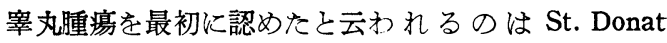
（1696）とされるが，分類についてはVirchow(1862）の 記載などが古いものであり, それ以後, 睪丸腫瘍は各種 の名称で呼ばれていたが，1906年に到りChevassu が畸 型腫と seminoma を対立させて鋅丸腫瘍の分類上注目 された. 現在に於ては多数の支持を得ている分類は,

1) Friedman および Moore によるもの 2), Dixon お よび Moore によるもの3), Melicow によるものなどで ある. 即ち，1)は鋅丸腫瘍を seminoma, embryonal carcinoma, teratocarcinoma, teratoma, interstitial cell tumor の5つに分けるむのであり，2)の Dixon 々 Moore によるものは腫瘍を 2 大別し， 1 つは精細胞 起源腫瘍で全体の $96.5 \%$ 占め, 他の 1 つ注粹丸の精細 胞以外の要素より起るものとして抢り, 更に精細胞起源 腫瘍を明解な模型図で表わし，大きく5群に分けるとし ているのは周知の事実である. 3)のMelicow によるもの はprimary testicular tumorを Dixon と Moore と同 様, germinal tumor $と$ nongerminal tumor $の 2 つ に$ 分けているが, germinal tumorについては, seminoma 群と embryoma, choriocarcinoma, embryonal carcinoma 群, およびこの 2 群の混合型乃至一部のものの 亞型から成る群の計 3 群に区別している，要するに昱 丸腫瘍の的 $95 \%$ ，原始胚細胞から発生した germinal, 所謂類畸型腫 teratoid tumor などと呼ばれるもので ある事に異論を唱えるものは少ない. Mooreは将来の分 類は胎生細胞癌と䄉毛上皮型を含んだ trophoblastoma 型と成熟畸型腫型と seminoma 型の 3 基本型で充分で あるとしている。いずれにせよ我々の症例は大きく云わ れる embryonal carcinoma の範疇に入る事に間違いな く, その周辺に seminoma 様の像を示したもの之思わ れる. 大田黒の最近の研究で注彼の49例の観察で, 基本型 としては seminoma, embryonal carcinoma, teratoma, の 3 群で, 時に, choriocarcinoma の要素である syncytium cellが混在するとし,さらに詳くし seminoma は stroma 抢よびリンパ球浸潤の態度により 4 型, 4 群 に分け得るとし，また embryonal carcinoma は精細管 内増殖後, 直ちに小囊胞乃至腺様構造をとる第 1 型と 
管䐑内に乳頭様增殖をする第 2 型と, 初期には未熟細胞 の増殖があり次第に惡性腺癌様構造を示す第 3 型と, さ らにての他 seminoma との移行型があるとし, 最後に teratoma にも各種の観察をしている. 以上の分類はと もかくとして我々の症例の惡性度は高く，組織所見でも 極めて未分化な細胞が多く, しかも発症に患者が気づい てから来院するまでに 1 年以上を経過しているので, 全 身各所に転移があるのに何等不思議はない. Campbel も睪丸腫瘍患者の $88 \%$ は初診時に既に転移を来たしてい たと報告した程である.

辤丸腫瘍の転移する場所のうち代表的なむのは所属淋 巴節, 鼠距部, 後腹膜胿, 頝部, 左鎖骨窩, 大網なぞ と, 肺, 肝, 腦, 胸膜, 樅隔洞等々であり, 沢山の報告 があるが，神㟝の如く眼窝へ来たものの報告もある。乙 れらの経路として大田黒は血行性, 淋巴性, 局所的浸潤 などを考えている，我々の症例についてみると，むしろ 転移の主たるものは皮下であるが，現在までの報告には 皮膚に対するものは殆んどなく,わずかに武井, 大田黒 などが, 頭部に腫留を認めたとしているが，乙れらも頭 蓋骨への転移か，頭部皮膚へのそれか明膫でない。また

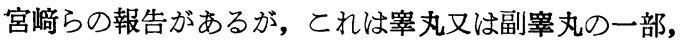

またこれに接続する組織に原発した腺癌が皮膚に連続転 移性に波及したものであり，遠隔性の転移ではない，我 々の症例はこの点で興味あるものと考える.

さらに本症例に使用したへマトポルフイリン水銀につ いてであるが, 本成は hematoporphyrin-diNa 塩の水 銀錯塩で, 黒褐色の水に易溶であるが, アルコールに僅 咜溶解する外は, クロロホルム, ベンゼン, アセトン なぞの有機溶媒に不溶の粉末である，本郕は白血球減少 がないと云われ，その他の副症状が少ないので長期間に 亘り抗腫瘍郕として使用し得ると云われる薬品である. また生体の新陳代謝を六進させ腫瘍より放出される有害 な物質に拮抗作用をもつものとも云われる.我々の症例 に於ては, 25mg25回使用時までは腫瘍に対して著明な効 果はみられなかつたが, 35 回使用後は腫瘍は急速に縮小 し, 胡桃大以下の睅丸胎生細胞癌皮下転移巣は消失する に至つた。このととはMHが本症に対しかなり有効なる ものと期待してよいと考える.

\section{まとめ}

65才男子の正常位左睪丸k発生した胎生細胞癌 と皮 下, 淋巴節, 頭蓋骨及び肺に転移巣を認めた症例を経験し た. 皮下及び頭蓋骨への転移は箤丸腫脹を気付いて後的 10力月後に発生したもので，殊に箤丸腫瘍の皮下転移は
極めて少いので貴重な症例として興味をひいた。病理組 織学的には睪丸腫痬は胎生細胞痁で，周囲を seminoma に囲まれている型を示し, 転移巣の組織像は胎生細胞䍌 であつた。

また新抗腫湯㐿へマトポルフィリン水銀製郕マーフィ リン25mg，35回の使用により大多数の皮下転移腫篦の消 失をみた．即ちこの成績より箤丸胎生細胞癌に対するへ マトポルフィリン水銀の効果を期待しろると考える.

（本論文の要旨は, 第36回日本泌尿器科学会信州地方 会において発表した）

\section{交献}

1）武井信：籴月報，24，29，1944（交献23ょり）.

2) Friedman, N.B. \& Moore, R.A.: Am. J. Military Surgeon, 99, 573, 1946.

3) Lowry, E.C. et al.: J. Urol., 55, 373, 1946.

4) Rusche, C.:J. Urol., 68, 340, 1952.

5) Dixon, F.J. \& Moore, R.A.: Armed Forces Institute of Pathology, Washington, D.C. 1952 ,

6）宮崎寛明他：臨皮泌，6，皮痛科図諳，1952.

7) Dixon, F.J. \& Moore, R.A.: Cancer, 6, 427, 1953.

8) Culp, D.A.: J. Urol., 70, 282, 1952.

9) Schwartz, J.W. \& Mallis, N.: J. Urol., 72, 404, 1954.

10) Thomas, G.J. et al.: J. Urol., 72, 411, 1954.

11) Campbell, M.S.: Urology, Vol. II., W.B. Saunders Company, 1954.

12）小田完五他 : 臨皮泌, 8, 297, 1954.

13）前川正信他：皮々泌，16，23，1954。

14) Melicow, M.M.: J. Urol., 73, 547, 1955.

15) Raines, S.L. \& Hurdle, T.G.: J. Urol., 73, $363,1955$.

16) Sohval, R.R.: J. Urol., 75, 285, 1956.

17) Melicow, M.M.: J. Internat. Coll. of Surgeons, $25,187,1956$.

18）松井滋他：臨皮泌，10，15，1956.

19）辻一郎：癌の臨床, $2,6,1956$.

20）中村邦昭他：臨皮泌， 11，186, 1957.

21）土屋交雄：日本外科全書, $\mathbb{I I} / 25$ 金原. 南江堂, 1958.

22）大田黒和生：日泌尿会誌，49，297, 1958.

23）柏井浩三 : 泌科紀要, 4,270,1958.

24）神崎教孝：眼臨， 52，1168，1958.

25) Patton, J.F.: J. Urol., 81, 457, 1959.

26）菅野英男他：臨皮泌，13，915, 1959.

27）石神褧次他：日本泌尿器科全書, VI/45, 金原 南江堂, 1960 . 